kester's name polyplast, which is to be preferred to Haeckel's morula.

In mosses, the agamobium never gets beyond this stage, the fully formed sporogonium being nothing more than a highly differentiated polyplast. But as in animals the polyplast is succeeded by a gastrula, i.e. a stage in which the characteristic organ of animal nutrition has appeared, so in vascular plants it is succeeded by a stage in which the characteristic organs of plant nutrition-the leaf and root-have made their appearance. From ferns up to Angiosperms the first important differentiation after the polyplast is the formation of a cotyledon and of the primary root. This stage, the obvious correlative of the animal gastrula, I propose to call the phyllula.

\section{XI. - On the Presence of a Sternum in Notidanus} indicus.

As far as I am aware, nothing answering to a sternum has hitherto been found in fishes, the Urodela being the lowest group in which this constituent of the skeleton is known. In them it consists of a median plate of cartilage formed from paired chondrites (independent cartilaginous elements) developed in the inscriptiones tendinex immediately caudad of the coracoids, and in close connection with them. In many Anuræ there is found in addition a median element cephalad of the procoracoids. The entire Amphibian sternum is conveniently called by Albrecht the omosternum, to distinguish it from the costal sternum of Amniota; the anterior division (omosternum, W. K. Parker) being called the pre-omosternum, the posterior division (xiphisternum, auct.) the post-omosternum. According to Wiedersheim ("Grundriss," 2te Auf., p. 58), the phylogeny of the Amphibian sternum is still entirely unknown.

In Elasmobranchs the shoulder-girdle has the form of an inverted arch, usually formed of a single continuous cartilage, due to the union in the middle ventral line of paired elements, one connected with each pectoral fin. In Hexanchus (Notidanus) the right and left sides are described by Hubrecht ("Bronn's Thierreich," Fische, p. 77) as being united by fibrous tissues.

In a skeleton of Notidanus indicus, recently prepared for this Museum, the middle region of the shoulder-girdle has the structure shown in the figure. It is produced in front into a blunt

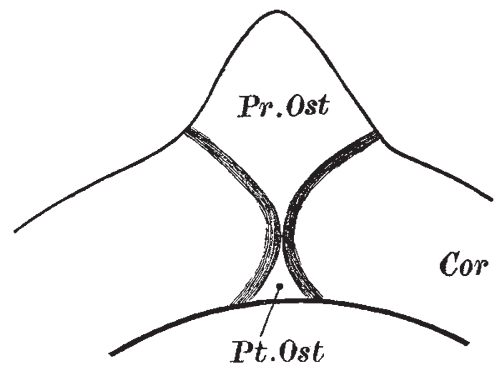

Median ventral region of the shoulder-girdle of Notidanus indicus, ventral aspect (natural size). Cor., coracoid region: Pr.Ost., pre-omosternum; Pt.Ost., post-omosternum.

process, while it is evenly curved posteriorly. Two curved areas of fibrous tissue, with their convexities towards the median plane, extend from the anterior to the posterior border, touching one another in the centre, and thus bounding two distinct cartilaginous areas-an anterior (Pr.Ost.) of a rhomboid, and a posterior $(P t$. Ost.) of a triangular form. The anatomical relations of these seem to show that the former is to be considered as a pre-omosternum, the latter as a post-omosternum.

The specimen in question appears to furnish a very good indication of the phylogeny of the sternum, and to show that it arose in the first instance by the segmentation of a mid-ventral element from the shoulder-girdle, in much the same way as the basi-hyal and basi-branchials are formed from the hyoid and branchial arches.

Dunedin, N.Z., September.

\section{UNIVERSITY AND EDUCATIONAL} INTELLIGENCE.

Cambridge.-Prof. M. J. M. Hill, of University College, London, has been approved for the degree of Doctor in Science.

NO. I IO2, VOL. 43$]$
Mr. H. W. Page, M.C., M.B., of Christ's College, has been appointed an additional Examiner in Surgery.

A. H. L. Newstead, B.A., of Christ's College, has been appointed by the Biology Board to occupy the University table in the Laboratory of the Zoological Station at Naples for six months from December 15,1890 .

Mr. J. Y. Buchanan, F.R.S., University Lecturer in Geography, announces a course of lectures in Physical Geography and Climatology for the ensuing Lent and Easter Terms.

The Clothworkers' Exhibition of fifty guineas a year in natural science for non-collegiate students will be awarded next July. Candidates are to apply to the Censor of Non-Collegiate Students.

The General Board of Studies recommend that Mr. R. T. Glazebrook, F.R.S., be appointed Assistant Director of the Cavendish Laboratory. Mr. Glazebrook resigns the Senior Demonstratorship which he has hitherto held.

A very interesting account is published in the University Reporter of December 9, I89o, of the course of study in natural science pursued by the University Extension students who were resident in Cambridge during the last Long Vacation. The course included invertebrate palæontology, practical chemistry, and physics. Courses were also given in Greek art, architecture, Egyptology, \&c. The Lectures Committee recommend that the experiment be repeated on a larger scale next year.

Additional demonstrators in physiology and in experimental physics are about to be appointed, to be paid out of the laboratory fees of students.

\section{SCIENTIFIC SERIALS}

THE Quarterly Fournal of Microscopical Science for November I 890 contains :- On the structure of a new genus of Oligochreta (Deodrilus), and on the presence of anal nephridia in Acanthodrilus, by Frank E. Beddard (plates xxxii. and xxxiii.). This large worm, Deodrilus jacksoni, measuring thirteen inches in length by nearly half an inch in diameter at the broadest part, was collected by Prof. Moseley in Ceylon; the nephridia in a species believed to be Acanthodrilus multiporus are described as connected with the terminal region of the intestine.-Excretory tubules in Amphioxus lanceolatus, by F. Ernest Weiss (plates xxxiv. and xxxv.). At the Zoological Station in Naples, the author was able to have a constant and unlimited supply of Amphioxus, and he took the opportunity of experimenting with the view of determining whether the curious patches of modified epithelial cells on the ventral wall of the atrium of Amphioxus had any excretory function, as Johannes Muller had held to be probable; and whether, also, the atrio-colomic funnels, first described by Prof. Ray Lankester, had any such function; positive results were not obtained.-Studies in mammalian embryology; ii. The development of the germinal layers of Sorex vulgaris, by Prof. A. W. Hubrecht (plates xxxvi. to xlii.). Giving a brief but very lucid sketch of the various views held by recent writers concerning the gastrulation process of the Amniota and the formation of their mesoblast and notochord, placing what is agreed on on the one side, and indicating the points of difference on the other, without any polemical remarks, the author proceeds to an account of the early developmental stages of Sorex, the blastula and the didermic blastocyst, the development of the mesoblast; then follow some theoretical considerations on the gastrulation of the Mammalia, concluding with points of comparison in earlier investigations by other authors. - Terminations of nerves in the nuclei of the epithelial cells of tortoiseshell, by Dr. J. B. Haycraft (plate xliii.). The scutes of the land tortoise (Testudo graca), in spite of their hard, dense nature, form a very typical epidermic sensory covering for the animal. As in the soft skin of mammals, the nerves end in localized sensitive spots in the epidermis, and before penetrating this tissue they form a horizontal plexus in the upper part of the connective tissue; figures of the nerve-endings are given.

\section{SOCIETIES AND ACADEMIES. LONDON.}

Royal Society, November 27.- "The Variations of Electromotive Force of Cells consisting of certain Metals, Platinum, and Nitric Acid." By G. J. Burch and V. H. Veley.

The description of the apparatus, the capillary electrometer, 